\title{
Oncologic Outcomes after Radical Retropubic Prostatectomy in Patients Meeting the Epstein Criteria
}

\author{
Cüneyt Özden, Binhan Kağan Aktaş, Mehmet Murat Baykam, Süleyman Bulut, Güven Erbay, Süleyman Tağcl, \\ Cevdet Serkan Gökkaya, Ali Memiş \\ Clinic of Urology, Ankara Numune Training and Research Hospital, Ankara, Turkey
}

\section{ABSTRACT}

Objective: The Epstein criteria are used for the prediction of clinically insignificant prostate cancer and the determination of the patients who are suitable for avoiding or delaying active treatments that have many potential serious side-effects. In the present study, we aimed to retrospectively evaluate and interpret the oncologic outcomes of the patients who underwent radical retropubic prostatectomy (RRP) but were potentially eligible for active surveillance based on the Epstein criteria.

Methods: Records of 305 patients who underwent RRP in our clinic between the years 2000 and 2014 for clinically localized prostate cancer were analyzed. Of these patients, 18 who met all the conditions of the Epstein criteria [clinical T1c, biopsy Gleason score (GS) $<7$, the number of cancer positive biopsy cores $<3$, cancer involvement in any core $<50 \%$, and prostate specific antigen (PSA) density $\left.<0.15 \mathrm{ng} / \mathrm{mL}^{2}\right]$ were included. The patients with an increased surgical specimen GS compared with that of biopsy or those with non-organ-confined disease were considered to have clinically significant disease.

Results: The mean age, serum PSA level, and prostate volume of all the 305 patients were $62.8 \pm 6.1$ years, $10.8 \pm 6.9 \mathrm{ng} / \mathrm{mL}$, and $46.2 \pm 22.1 \mathrm{~mL}$, respectively. Eighty-six patients (28.2\%) were with extracapsular extension (ECE), 58 (19.0\%) with positive surgical margin (PSM), 39 (12.8\%) with seminal vesicle invasion (SVI), and 16 (5.2\%) with lymph node involvement (LNI). Biochemical recurrence was detected in 55 of the 305 patients (20.9\%) during the mean follow-up period of $71.2 \pm 37.3$ months after RRP. Of the 305 patients who underwent RRP, 18 (5\%) met the Epstein criteria. The mean age, serum PSA level, and prostate volume of these patients were $61.6 \pm 6.01$ years, $5.51 \pm 1.1 \mathrm{ng} / \mathrm{mL}$, and $45.2 \pm 10.13 \mathrm{~mL}$, respectively. Five patients (27.8\%) were with extracapsular extension (ECE), 4 (22.5\%) with an increased GS, and 1 (5.5\%) with both ECE and increased GS. A total of eight patients (44.4\%) were detected to have clinically significant disease. None of the patients was with SVI or LNI. Biochemical recurrence was not detected in any of the patients during the mean follow-up period of $48.7 \pm 31.2$ months after RRP.

Conclusion: Our results showed that the Epstein criteria may misguide us for the prediction of clinically insignificant prostate cancers. A notable proportion of our patients potentially eligible for active surveillance based on the Epstein criteria were postoperatively revealed to have clinically significant disease. If those patients had not undergone surgery, they may have lost their chance to undergo active treatment for their cancer. (JAREM 2015; 5: 6-9)

Keywords: Neoplasm grading, pathology, prostate adenocarcinoma, prostate cancer, retropubic prostatectomy, surveillance

\section{INTRODUCTION}

Prostate cancer is the most frequently observed cancer in males and is the second leading cause of deaths after lung cancer (1). Widespread usage of prostate-specific antigen (PSA) screening, aging of world population, increase in the number of biopsy cores, and increase in the experience of radiologists or urologists performing biopsies resulted in an increase in the number of patients diagnosed with prostate cancer. Parallel to the increase in the number of patients, the number of clinically insignificant prostate cancers also increased, which brought forth the question, "are we over-treating patients with prostate cancer?" Studies determined that to prevent the death of 1 patient, 48 patients are treated, and that widely accepted recent surveillance policies decrease this number to 37 (2). To decrease the number of over-treated patients, Epstein et al. (3) defined the "clinically insignificant prostate cancer" criteria in 1994. There criteria are as follows: clinical stage T1c, PSA density of $<0.15 \mathrm{ng} / \mathrm{mL}^{2}$, Glea- son score (GS) of $<7$, number of positive biopsy cores of $<3$, and tumor involvement per core of $<50 \%$. This is followed by the appearance of the concept of active surveillance in prostate cancer; the aim of this study is to monitor the patients with low-risk prostate cancer with rapid PSA measurements, digital rectal examination, and repeated prostate biopsies as well as to detect the progression of the disease early to increase the patients' chances of recovering from the disease (4). However, the sufficiency of Epstein criteria in detecting clinically insignificant prostate cancer still remains controversial $(5,6)$. In this study, the oncologic results of the patients conforming to the Epstein criteria among the patients who underwent radical retropubic prostatectomy (RRP) because of clinically localized prostate cancer are evaluated.

\section{METHODS}

A total of 305 patients who underwent RRP because of clinically localized prostate cancer in our clinic between 2000 and 2014 were included in the study. Clinical and pathological data of the 
patients were retrospectively evaluated. Because of the retrospective design of the study, approval of the ethics committee and consents of the patients were not obtained. Prostate cancer diagnosis was established after PSA elevation (>4 $\mathrm{ng} / \mathrm{mL}$ ) and/or after taking biopsy because of the discovery of a nodule during digital rectal examination. Biopsies, at least 10 cores, were taken with the ultrasonography device Hitachi EUB-420 (Hitachi Medical Corp, Tokyo, Japan) using 6.5-Mhz biplanar transrectal probe and 18-G biopsy needle.

In the pathological examination of the surgical specimens after RRP, tumor cells on the surgical margin were interpreted as positive surgical margin (PSM), tumor cells exceeding the prostate capsule were interpreted as extracapsular extension (ECE), tumor cells infiltrating the muscular wall was interpreted as seminal vesicle invasion $(\mathrm{SVI})$, and patients without prostate capsule involvement were reported as organ confined. In clinical and pathological staging, 2002 tumor, node, and metastasis (TNM) staging system was used. After the operation, patients were followed up once every 3 months in the $1^{\text {st }}$ year, once every 6 months between the $2^{\text {nd }}$ and $5^{\text {th }}$ years, and once a year after the $5^{\text {th }}$ year. Serum PSA threshold value was taken as $\geq 0.2 \mathrm{ng} / \mathrm{mL}$ for biochemical recurrence after RRP. Among the patients who preoperatively met the Epstein criteria, those who showed an elevation in their surgical specimen GS after RRP or those whose tumors spread out of the prostate were accepted as clinically significant cancer.

\section{Statistical Analysis}

Descriptive statistical methods, mean, and standard deviation are used in the evaluation of the quantitative data of the study. Hence, 13.0 version of the Statistical Package for Social Sciences (SPSS Inc., Chicago, IL, USA) program is utilized.

\section{RESULTS}

The mean age of all patients $(n=305)$ was $62.8 \pm 6.1$ years, serum PSA level was $10.8 \pm 6.9 \mathrm{ng} / \mathrm{mL}$, and prostate volume was $46.2 \pm 22.1 \mathrm{~mL}$. In the surgical specimen pathology reports, 86 patients (28.2\%) had ECE, 58 (19.0\%) had PSM, 39 (12.8\%) had SVI, and 16 (5.2\%) had LNI. Clinical and pathological features of the patients are shown in Table 1. With an average of 71.2 \pm 37.3 months of follow-up, biochemical recurrence was detected in 55 of the patients (20.9\%).

Of all the patients who underwent RRP, 18 (5\%) were confirmed to meet the Epstein criteria. The mean age of these patients was $61.6 \pm 6.01$ years, serum PSA level was $5.51 \mathrm{ng} / \mathrm{mL}$, and prostate volume was $45.2 \pm 10.13 \mathrm{~mL}$. ECE was detected in five patients (27.8\%), elevation in GS was detected in four (22.5\%), and both ECE and elevation in GS were detected in one (5.5\%). Clinically significant cancer was detected in a total of eight patients (44.4\%). None of the patients had PSM, SVI, and LNI. Clinical and pathological data of these patients are shown in Table 2. With an average of $48.7 \pm 31.2$ months of follow-up after RRP, biochemical recurrence was not detected in any of these patients.

\section{DISCUSSION}

Nowadays, with the widespread clinical usage of PSA, diagnoses of early stage prostate cancer increased and deaths caused by prostate cancer significantly decreased with early interven-
Table 1. Clinical and pathological data of all patients who underwent RRP

\begin{tabular}{|c|c|c|}
\hline Age (years) & & $62.8 \pm 6.1$ \\
\hline PSA (ng/mL) & & $10.8 \pm 6.9$ \\
\hline Prostate volume $(\mathrm{mL})$ & & $46.2 \pm 22.1$ \\
\hline PSA density (ng/mL $\left.{ }^{2}\right)$ & & $0.26 \pm 0.18$ \\
\hline Biopsy GS & & $5.7 \pm 1.4$ \\
\hline Biopsy core number & & $9.4 \pm 1.8$ \\
\hline Number of positive biopsy cores & & $3.6 \pm 2.4$ \\
\hline Clinical stage & $\mathbf{n}$ & $\%$ \\
\hline T1a & 12 & 3.9 \\
\hline $\mathrm{T} 1 \mathrm{~b}$ & 28 & 9.2 \\
\hline T1c & 122 & 40.0 \\
\hline $\mathrm{T} 2 \mathrm{a}$ & 78 & 25.6 \\
\hline $\mathrm{T} 2 \mathrm{~b}$ & 44 & 14.4 \\
\hline $\mathrm{T} 2 \mathrm{c}$ & 21 & 6.9 \\
\hline Pathological stage & $\mathbf{n}$ & $\%$ \\
\hline T0 & 2 & 0.7 \\
\hline $\mathrm{T} 2 \mathrm{a}$ & 92 & 30.2 \\
\hline $\mathrm{T} 2 \mathrm{~b}$ & 83 & 27.2 \\
\hline $\mathrm{T} 2 \mathrm{c}$ & 20 & 6.6 \\
\hline T3a & 65 & 21.3 \\
\hline T3b & 43 & 14.1 \\
\hline \multicolumn{2}{|l|}{ GS in RRP specimen } & $6.2 \pm 1.4$ \\
\hline \multirow[t]{2}{*}{ Positive surgical margin } & n & $\%$ \\
\hline & 58 & 19 \\
\hline \multirow[t]{2}{*}{ Lymph node involvement } & $\mathbf{n}$ & $\%$ \\
\hline & 16 & 5.2 \\
\hline \multicolumn{3}{|c|}{$\begin{array}{l}\text { RRP: radical retropubic prostatectomy; PSA: prostate-specific antigen; GS: } \\
\text { Gleason score }\end{array}$} \\
\hline
\end{tabular}

tions (7). However, there are concerns regarding over-treatment of some of the patients with prostate cancer (8). Diagnosis and treatment costs for a potentially harmless disease are also a serious problem. In a recent study, Wilt et al. (9) compared patients with prostate cancer who underwent radical surgery and were surveilled in terms of death rates because of cancer and did not find a significant difference. For the abovementioned reasons, the concept of "watchful waiting" arose, i.e., waiting without any treatment until metastasis or locally advanced disease findings appear in patients who initially had clinically insignificant prostate cancer (10). However, as a result of findings indicating that the chances of a cure in patients who are followed up solely by watchful waiting are decreased, this method is currently limited to patients who have life expectancies of $\leq 5$ years because of their age and comorbidities (11). The method of watchful waiting 
Table 2. Clinical and pathological data of patients who met the Epstein criteria among those who underwent RRP

\begin{tabular}{|c|c|c|}
\hline \multicolumn{2}{|l|}{ Age (years) } & $61.6 \pm 6.01$ \\
\hline \multicolumn{2}{|l|}{ PSA (ng/mL) } & $5.51 \pm 1.1$ \\
\hline \multicolumn{2}{|l|}{ Prostate volume $(\mathrm{mL})$} & $45.2 \pm 10.13$ \\
\hline \multicolumn{2}{|l|}{ PSA density $\left(\mathrm{ng} / \mathrm{mL}^{2}\right)$} & $0.12 \pm 0.02$ \\
\hline \multicolumn{2}{|l|}{ Biopsy GS } & $5.83 \pm 0.9$ \\
\hline \multicolumn{2}{|l|}{ Biopsy core number } & $10.2 \pm 0.6$ \\
\hline \multicolumn{2}{|c|}{ Number of positive biopsy cores } & $1.4 \pm 0.5$ \\
\hline Clinical stage & $\mathrm{n}$ & $\%$ \\
\hline T1c & 18 & 100 \\
\hline Pathological stage & $\mathrm{n}$ & $\%$ \\
\hline $\mathrm{T} 2 \mathrm{a}$ & 3 & 16.7 \\
\hline $\mathrm{T} 2 \mathrm{~b}$ & 9 & 50.0 \\
\hline $\mathrm{T} 2 \mathrm{c}$ & 1 & 5.6 \\
\hline Т3а & 5 & 28.8 \\
\hline GS in RRP specimen & & $5.9 \pm 0.6$ \\
\hline $\begin{array}{l}\text { RRP: radical retropubic pr } \\
\text { Gleason score }\end{array}$ & & fic antigen; GS: \\
\hline
\end{tabular}

is later supported by the concept of active surveillance; although the number of watchfully waited patients eventually decreased, the number of actively surveilled patients increased. Active surveillance provides advantages for patients with clinically insignificant prostate cancer such as avoiding unnecessary treatments, maintaining quality of life, and reducing treatment cost; on the other hand, it includes disadvantages such as progression of patients' cancer and loss of the chance of a cure $(5,6)$. Therefore, choosing patients appropriately for active surveillance is critically important. Various clinical nomograms are defined and confirmed in determining selection criteria (12). Among these, Epstein criteria are one of the most practical and useful criteria in terms of their clinical use in predicting clinically insignificant prostate cancer patients. According to the reports of National Comprehensive Cancer Network (NCCN), Epstein criteria provide clinically useful information. However, the results of some studies evaluating the Epstein criteria were disappointing. Active surveillance protocol of patients determined by these criteria includes intermittent digital rectal examination, PSA measurement, and rebiopsies. Among these, the most important is the rebiopsy that is performed within 1 year after the initial biopsy because the initial biopsy can fail to detect a high-level disease (13). If the cancer is negative or if the result in the first rebiopsy is the same as that in the initial biopsy, the interval between the biopsies can be increased up to $1-2$ years. Elevation in GS rates from $28 \%$ to $37 \%$ is observed in the follow-up biopsies of patients with clinically insignificant prostate cancer (14-16). On an average, definitive treatment is pursued in $33 \%$, of the patients who are included in the active surveillance protocol within the first 5 years and in
$55 \%$ within 10 years (17). In the pathology results of the patients who underwent radical surgery following active surveillance, elevation rates in GS are observed to be between $16 \%$ and $45.9 \%$ $(6,18-22)$. Subsequently, the relationship between elevation in GS and the number of biopsy cores is investigated; in a large data analysis, it is reported that GS elevation is inversely proportional to taking biopsies of $>8$ cores (23). In particular, it is maintained that the score increase in GS 6 patients with radiotherapy options are clinically more important because if it is discovered prior to the treatment that these patients are GS 7, they have a chance to be administered with radiotherapy or hormone treatment. Extended biopsy schemes are widely used over the last 10 years because of an increase in the detection of cancer. Consistence between GS after biopsy and RRP, increases in parallel with the number of biopsy cores (24-26).

Another problem in active surveillance is inadequacy in radiological imaging. Ultrasonography or computed tomography does not provide sufficient information to the clinician in patients with lowvolume prostate cancer. However, multiparametric magnetic resonance imaging (mp-MRI) recently yielded promising results. MpMRI provides detailed anatomical information regarding suspected intraprostatic lesions. Furthermore, it can detect SVI and ECE as well as pelvic $L N I$ at satisfactory levels in the follow-up of patients who are deemed as clinically insignificant. Its sensitivity is reported as $>80 \%$ and specificity is reported as $>90 \%$ in the latest series $(27-$ 30). However, the results of mp-MRI are not yet included within the scope of active surveillance criteria or decision algorithm.

In this study, the elevation rates in GS and the rates of ECE after radical surgery when compared with biopsy are found to be consistent with those reported in the literature. According to our results, approximately $25 \%$ of our patients, a significant ratio, are not suitable for active surveillance. If the Epstein criteria are followed and active surveillance is performed in our patients instead of radical surgery, they may lose the chances of a curative treatment.

\section{CONCLUSION}

Epstein criteria alone appear to be insufficient in determining clinically insignificant patients who need to be actively surveilled. Therefore, we maintain that more efficient new nomograms are needed to choose suitable patients for active surveillance.

Ethics Committee Approval: Due to the retrospective design of the study, ethics committee approval was not taken.

Informed Consent: Due to the retrospective design of the study, informed consent was not taken.

Peer-review: Externally peer-reviewed.

Author contributions: Concept - C.Ö., C.S.G., B.K.A.; Design - C.Ö., C.S.G., A.M.; Supervision - C.Ö., B.K.A.; Resource - G.E., S.T., A.M.; Data Collection and/or Processing - M.M.B., G.E., S.T.; Analysis and/or Interpretation - S.B., S.T., A.M.; Literature Search - G.E., C.S.G.; Writing - S.B., M.M.B.; Critical Reviews - B.K.A., S.B., M.M.B.

Conflict of Interest: No conflict of interest was declared by the authors.

Financial Disclosure: The authors declared that this study has received no financial support. 


\section{REFERENCES}

1. Jemal A, Siegel R, Ward E, Murray T, Xu J, Thun MJ. Cancer statistics, 2007. CA Cancer J Clin 2007; 57: 43-66. [CrossRef]

2. Schröder FH, Hugosson J, Roobol MJ, Tammela TL, Ciatto S, Nelen $V$, et al. Prostate-cancer mortality at 11 years of follow-up. N Engl J Med 2012; 366: 981-90.[CrossRef]

3. Epstein JI, Carmichael MJ, Partin AW, Walsh PC. Small high grade adenocarcinoma of the prostate in radical prostatectomy specimens performed for nonpalpable disease: pathogenetic and clinical implications. J Urol 1994; 151: 1587-92.

4. Cooperberg MR, Carroll PR, Klotz L. Active surveillance for prostate cancer: progress and promise. J Clin Oncol 2011; 29: 3669-76. [CrossRef]

5. Chun FK, Haese A, Ahyai SA, Walz J, Suardi N, Capitanio U, et al. Critical assessment of tools to predict clinically insignificant prostate cancer at radical prostatectomy in contemporary men. Cancer 2008; 113: 701-9. [CrossRef]

6. Sundi D, Ross AE, Humphreys EB, Han M, Partin AW, Carter HB, et al. African American men with very low-risk prostate cancer exhibit adverse oncologic outcomes after radical prostatectomy: should active surveillance still be an option for them? J Clin Oncol 2013; 31: 2991-7. [CrossRef]

7. Bray F, Lortet-Tieulent J, Ferlay J, Forman D, Auvinen A. Prostate cancer incidence and mortality trends in 37 European countries: an overview. Eur J Cancer 2010; 46: 3040-52. [CrossRef]

8. Draisma G, Boer R, Otto SJ, van der Cruijsen IW, Damhuis RA, Schröder $\mathrm{FH}$, et al. Lead times and overdetection due to prostate-specific antigen screening: estimates from the European Randomized Study of Screening for Prostate Cancer. J Natl Cancer Inst 2003; 95: 868-78. [CrossRef]

9. Wilt TJ, Brawer MK, Jones KM, Barry MJ, Aronson WJ, Fox S, et al. Radical prostatectomy versus observation for localized prostate cancer. N Engl J Med 2012; 367: 203-13. [CrossRef]

10. Bill-Axelson A, Holmberg L, Filén F, Ruutu M, Garmo H, Busch C, et al. Radical prostatectomy versus watchful waiting in localized prostate cancer: the Scandinavian prostate cancer group-4 randomized trial. J Natl Cancer Inst 2008; 100: 1144-54. [CrossRef]

11. Klotz L. Active surveillance for prostate cancer: overview and update. Curr Treat Options Oncol 2013; 14: 97-108. [CrossRef]

12. Bastian PJ, Carter BH, Bjartell A, Seitz M, Stanislaus P, Montorsi F, et al. Insignificant prostate cancer and active surveillance: from definition to clinical implications. Eur Urol 2009; 55: 1321-30. [CrossRef]

13. Adamy A, Yee DS, Matsushita K, Maschino A, Cronin A, Vickers A, et al. Role of prostate specific antigen and immediate confirmatory biopsy in predicting progression during active surveillance for low risk prostate cancer. J Urol 2011; 185: 477-82. [CrossRef]

14. Bul M, Zhu X, Rannikko A, Staerman F, Valdagni R, Pickles T, et al. Radical prostatectomy for low-risk prostate cancer following initial active surveillance: results from a prospective observational study. Eur Urol 2012; 62: 195-200. [CrossRef]

15. Dall'Era MA, Konety BR, Cowan JE, Shinohara K, Stauf F, Cooperberg $M R$, et al. Active surveillance for the management of prostate cancer in a contemporary cohort. Cancer 2008; 112: 2664-70. [CrossRef]
16. Klotz L, Zhang L, Lam A, Nam R, Mamedov A, Loblaw A. Clinical results of long-term follow-up of a large, active surveillance cohort with localized prostate cancer. J Clin Oncol 2010; 28: 126-31. [CrossRef]

17. Thomsen FB, Brasso K, Klotz LH, Røder MA, Berg KD, Iversen P. Active surveillance for clinically localized prostate cancer - a systematic review. J Surg Oncol 2014; 109: 830-5. [CrossRef]

18. Bastian PJ, Mangold LA, Epstein JI, Partin AW. Characteristics of insignificant clinical T1c prostate tumors. A contemporary analysis. Cancer 2004; 101: 2001-5. [CrossRef]

19. Jeldres C, Suardi N, Walz J, Hutterer GC, Ahyai S, Lattouf JB, et al. Validation of the contemporary Epstein criteria for insignificant prostate cancer in European men. Eur Urol 2008; 54: 1306-13. [CrossRef]

20. Lee SE, Kim DS, Lee WK, Park HZ, Lee CJ, Doo SH, et al. Application of the Epstein criteria for prediction of clinically insignificant prostate cancer in Korean men. BJU Int 2010; 105: 1526-30. [CrossRef]

21. Mufarrij P, Sankin A, Godoy G, Lepor H. Pathologic outcomes of candidates for active surveillance undergoing radical prostatectomy. Urology 2010; 76: 689-92. [CrossRef]

22. Kane CJ, Im R, Amling CL, Presti JC Jr, Aronson WJ, Terris MK, et al. Outcomes after radical prostatectomy among men who are candidates for active surveillance: results from the SEARCH database. Urology 2010; 76: 695-700. [CrossRef]

23. Freedland SJ, Kane CJ, Amling CL, Aronson WJ, Terris MK, Presti JC Jr. Upgrading and downgrading of prostate needle biopsy specimens: risk factors and clinical implications. Urology 2007; 69: 495-9. [CrossRef]

24. King CR, McNeal JE, Gill H, Presti JC Jr. Extended prostate biopsy scheme improves reliability of Gleason grading: implications for radiotherapy patients. Int J Radiat Oncol Biol Phys 2004; 59: 386-91. [CrossRef]

25. Makhlouf AA, Krupski TL, Kunkle D, Theodorescu D. The effect of sampling more cores on the predictive accuracy of pathological grade and tumour distribution in the prostate biopsy. BJU Int 2004; 93: 271-4. [CrossRef]

26. Coogan CL, Latchamsetty KC, Greenfield J, Corman JM, Lynch B, Porter CR. Increasing the number of biopsy cores improves the concordance of biopsy Gleason score to prostatectomy Gleason score. BJU Int 2005; 96: 324-7. [CrossRef]

27. Muller BG, van den Bos W, Pinto PA, de la Rosette JJ. Imaging modalities in focal therapy: patient selection, treatment guidance, and follow-up. Curr Opin Urol 2014; 24: 218-24. [CrossRef]

28. Lista F, Gimbernat H, Cáceres F, Rodríguez-Barbero JM, Castillo E, Angulo JC. Multiparametric magnetic resonance imaging for the assessment of extracapsular invasion and other staging parameters in patients with prostate cancer candidates for radical prostatectomy. Actas Urol Esp 2014; 38: 290-7. [CrossRef]

29. Otto J, Thörmer G, Seiwerts M, Fuchs J, Garnov N, Franz T, et al Value of endorectal magnetic resonance imaging at $3 T$ for the local staging of prostate cancer. Rofo 2014; 186: 795-802. [CrossRef]

30. Raskolnikov D, George AK, Rais-Bahrami S, Turkbey B, Shakir NA, Okoro $C$, et al. Multiparametric magnetic resonance imaging and image-guided biopsy to detect seminal vesicle invasion by prostate cancer. J Endourol 2014; 28: 1283-9. [CrossRef] 